\title{
Geometric morphometric analysis of the head of Microlophus atacamensis (Tropiduridae) in a latitudinal gradient
}

\author{
Soledad Ibáñez ${ }^{1 *}$, Marcela A Vidal', Juan Carlos Ortiz² and Fernando Torres-Pérez ${ }^{3}$
}

\begin{abstract}
Background: Clinal variation is defined as gradual variation in a character associated with geographic distance among sites. Microlophus atacamensis is a medium large lizard species which inhabits the intertidal zone of

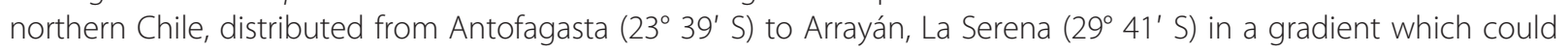
show clinal variation. Geometric morphometrics analyzes differences in shape independent of size; information about shape allows a more complete biological interpretation than information on morphological variation. This study evaluated clinal variation in the head shape of M. atacamensis from five localities (Antofagasta, Paposo, Pan de Azúcar, Caldera, and Tres Playitas) using dorsal and lateral views, comparing form variation with latitudinal distribution. The heads of adults collected were photographed in lateral and dorsal views.
\end{abstract}

Results: The analysis did not find significant differences in form among the five localities, in contrast to the proposal of earlier studies, and no differences were recorded between the sexes. Possible reasons why these populations are not differentiated in the latitudinal gradient are discussed.

Conclusions: Our results show that there are no differences between the studied, among the explanations are that populations of this species are subjected to similar environments that promote convergence of the structures analyzed.

Keywords: Atacama Desert; Lizard; Shape morphometrics; Head

\section{Background}

The genus Microlophus (Squamata: Tropiduridae) has a disjunct distribution, rare in terrestrial vertebrates (Benavides et al. 2007). Twenty-one species are recognized; nine of these are found only in the Galapagos Islands, while the remainder are distributed along the coast and interior deserts of western South America, from southern Ecuador to northern Chile (Etheridge and De Queiroz 1988; Frost and Etheridge 1989; Frost 1992; Benavides et al., 2007). The species of the genus Microlophus form a monophyletic group of lizards, characterized by apical disks in the hemipenis (Frost 1992). According to Dixon and Wright (1975), two groups are recognized in the genus whose monophyly is justified by characters of body scales and skin folds, occipitalis and peruvianus; this was later corroborated by Frost (1992)

\footnotetext{
* Correspondence: soledadibanez7@gmail.com

'Departamento de Ciencias Básicas, Facultad de Ciencias, Universidad del Bío-Bío, Casilla 447, 4051381 Chillán, Chile

Full list of author information is available at the end of the article
}

with osteological characters. Two subgroups are recognized within the peruvianus group; the first group groups interior species which feed on insects and terrestrial plants with no direct ecological relation to the intertidal zone: $M$. peruvianus, $M$. thoracicus, $M$. theresioides, M. tigris, M. yanezi, M. theresiae, and M. tarapacensis (Ortiz and Serey 1979); the second group is composed of intertidal species which feed on crustaceans and algae: $M$. heterolepis, $M$. atacamensis, and $M$. quadrivittatus (Ortiz and Serey 1979). In Chile, this genus is currently represented by $M$. atacamensis, $M$. quadrivittatus, M. yanezi, M. tarapacensis, M. theresioides, and M. heterolepis (Ortiz 1980a), which are distributed from Arica to Arrayán (La Serena) (DonosoBarros 1949; Sepúlveda et al. 2006).

According to Donoso-Barros (1960), the origin of the genus Microlophus in Chile began with M. peruvianus, which would have descended southward along the coast and then extended its range to the interior desert by way of the valleys. Ortiz (1980a) followed this logic but 
added that the distribution to the interior desert would have occurred through the Pampa del Tamarugal. Later, using isoenzyme data Victoriano et al. (2003) proposed that an ancestral lineage advanced from Peru towards the coast and later diverged into two groups; one was the ancestor of the $M$. quadrivitattus-M. theresioides group (one of whose subgroups still inhabits the interior desert) and the other was the ancestor of $M$. atacamensis. Based on a molecular phylogeny of data from many genes, Benavides et al. (2007) proposed that the origin of the Chilean clade was a migration from Peru to the interior desert; $M$. theresioides diverged and then dispersed along the Río Loa to the coast, giving rise to M. quadrivittatus in the north and $M$. atacamensis farther south. This last proposal is questionable, since the limit of distribution between $M$. quadrivittatus and $M$. atacamensis is near Antofagasta (Victoriano et al. 2003). Here, we describe some characteristics of $M$. atacamensis.

$M$. atacamensis is a lizard species which inhabits the intertidal zone of northern Chile from Antofagasta $\left(23^{\circ}\right.$ $\left.39^{\prime} \mathrm{S}, 70^{\circ} 22^{\prime} \mathrm{W}\right)$ to Arrayán, La Serena $\left(29^{\circ} 41^{\prime} \mathrm{S}, 71^{\circ}\right.$ 19' W) (Ortiz 1980b; Heisig 1993, Sepúlveda et al. 2006). This is a medium large (mean: $102.7 \mathrm{~mm}$ length) (DonosoBarros 1966; Ortiz 1980b), corpulent species with dark brown color and black blotches on the dorsum; crest tenuous in the vertebral zone and mouth narrow. According to Ortiz (1980a) and Vidal et al. (2002) there is a spatial segregation between juveniles and adults in the height of the perch used for thermoregulation, as well as a difference between sexes; although males are larger, there was no significant difference in their regulation, both were thermoconformers (Vidal et al. 2002). This species is omnivorous behavior, since they consumed mainly Diptera and algae obtained from the intertidal area (Ortiz 1980a; Vidal and Labra 2008; Fariña et al. 2008).

Clinal variation is defined as gradual variation of a character over geographic distance (Futuyma 1998). For example, Vidal et al. (2007) found latitudinal variation in coloration in Liolaemus tenuis; green increased and brown decreased from north to south. Sepúlveda et al. (2008) proposed a latitudinal gradient in the thermoregulatory ability of $M$. atacamensis, in which northern populations have low average to which lizards experience a $\mathrm{Tb}$ outside the selected temperature, while south this ability increases. Fariña et al. (2008) found a clinal pattern in the diet of $M$. atacamensis, in which algal consumption decreases and consumption of Diptera increases from north to south.

Many theoretical and empirical studies have focused on the adaptive significance of morphological clinal variation (Trussell 2000; Martínez-Freiría et al. 2009). While some analyses of linear morphometry have been often used to test hypotheses related to morphological polymorphism in a microevolutionary context (Endler 1977;
Scolaro and Cei 1987; Quatrini et al. 2001), others are more holistic and quantitative analyses are then required to identify them and to appraise the selective forces responsible for their evolution (Adams and Rohlf 2000). In fact, due to scale problems with linear measures, these do not take into account the morphological complexity of biological structures (Humphries et al. 1981; Rohlf and Bookstein 1987; Mousseau 1991; Warheit 1992). In the case of traditional (non-geometric) measurements, statistical techniques for measuring distances, relations among distances, areas, volumes, or angles are applied (Bookstein et al. 1999). However, the geometric morphometry preserves the geometry configurations of landmarks, by allowing a statistical representation of real forms or forms only (Rohlf and Slice 1990; Rohlf et al. 1996; Rohlf 1999; Rohlf and Corti 2000), whereas denotes the geometric shape properties of a structure that is independent of size, position, and orientation of the same, while the form of an object includes both size and shape (Rohlf and Slice 1990; Adams and Rohlf 2000, Mitteroecker and Gunz 2009). This information on shape allows a more complete biological interpretation than morphological variation (Rohlf and Marcus 1993). In relation to clinal variation, results obtained in Liolaemus show that, although there is not a clear pattern of latitudinal variation of the shape in $L$. tenuis (Vidal et al. 2005), there are significant differences between two geographical areas (arid Mediterranean and oceanic with Mediterranean influence). These different geographic areas may act as partial barriers to gene flow in this species. Vidal et al. (2006) found divergence between $L$. pictus from the Isla de Chiloé and the Chilean continent in ocular extension and location of the labial commissure. Individuals from the island had more extended ocular orbits and a more posterior position of the labial commissure than individuals from the continent, which may be attributed to differences in diet between these two localities (Vidal et al. 2006).

In this study, we explored the morphological adjustment to clinal environment variation in the shape of the head of M. atacamensis in dorsal and lateral view in different localities, comparing over a latitudinal distribution from $23^{\circ}$ to $28^{\circ} \mathrm{S}$. Considering that environmental temperature decreases as latitude increases and previous data has shown variation in thermal and feeding in this species, we specifically attempted to test the hypotheses that the shape of the head varies latitudinally including more extended shape in the north for your diet and more compacted shape the south.

\section{Methods}

We examined 111 adult individuals of $M$. atacamensis from the following localities (Figure 1, Table 1): Antofagasta, Paposo, Pan de Azúcar, Caldera, and Tres 


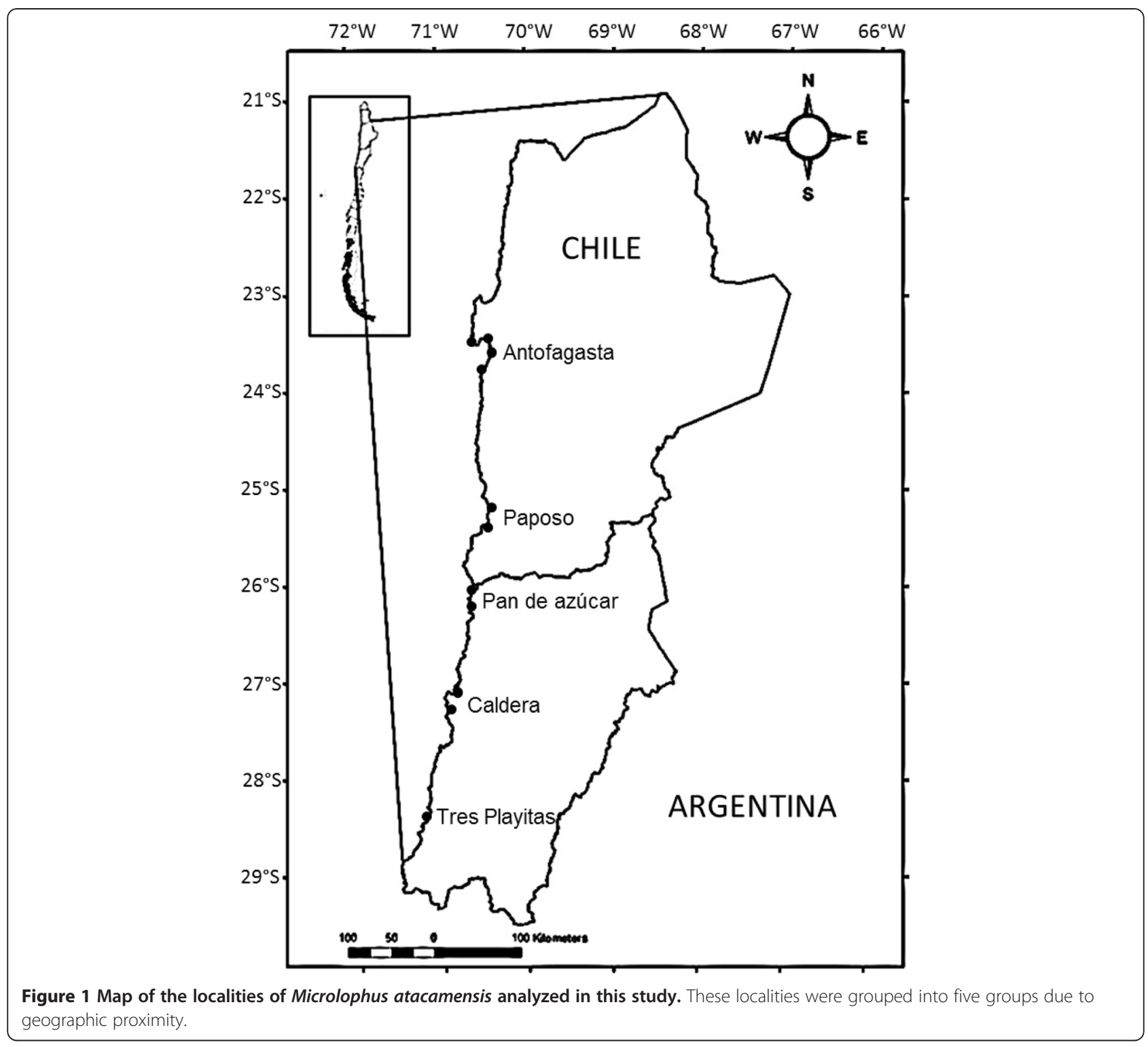

Playitas. The localities were grouped into five groups, due to their geographic proximity to the mentioned localities. All material is deposited in the Museo de Zoología of the Universidad de Concepción (MZUC). Digital photographs were taken of the head of each individual in dorsal and

Table 1 Studied localities and their geographic coordinates

\begin{tabular}{|c|c|c|c|}
\hline \multirow[t]{2}{*}{ Locality } & \multirow[t]{2}{*}{ Geographic coordinates } & \multirow{2}{*}{$\begin{array}{l}N \\
\text { Dorsal view }\end{array}$} & \multirow{2}{*}{$\begin{array}{l}N \\
\text { Lateral view }\end{array}$} \\
\hline & & & \\
\hline Antofagasta & $23^{\circ} 37^{\prime} \mathrm{S}, 70^{\circ} 24^{\prime} \mathrm{W}$ & 36 & 31 \\
\hline Paposo & $25^{\circ} 15^{\prime} \mathrm{S}, 70^{\circ} 23^{\prime} \mathrm{W}$ & 3 & 2 \\
\hline Pan de Azúcar & $26^{\circ} 04^{\prime} \mathrm{S}, 70^{\circ} 35^{\prime} \mathrm{W}$ & 15 & 14 \\
\hline Caldera & $27^{\circ} 04^{\prime} \mathrm{S}, 70^{\circ} 49^{\prime} \mathrm{W}$ & 26 & 25 \\
\hline Tres Playitas & $28^{\circ} 27^{\prime} \mathrm{S}, 71^{\circ} 13^{\prime} \mathrm{W}$ & 6 & 8 \\
\hline
\end{tabular}

$N=$ sample size. lateral views with a dSLR Canon T4 camera (Canon, Tokyo, Japan), using a 50-mm f/1.4 lens with a fixed focal length. In addition, specimens were placed $10 \mathrm{~cm}$ away from the camera using a fixed tripod. The quality of the photographs was optimized with the Microsoft Power Point 2010 program. Nine homologous landmarks were located in the dorsal view and eleven in the lateral view (Figure 2), coincident with intersections of cranial scales. The location of the homologous landmarks was performed using the proposal of Vidal et al. (2006), with the addition of new landmarks which are specific for the genus Microlophus. Coordinates were sampled from photographs in dorsal and lateral view by using tpsDig 1.20 (Rohlf 2003a). The analyses followed the procedures of Rohlf and Slice (1990) and Rohlf et al. (1996). The X and Y coordinates of the biologically homologous landmarks were aligned and 


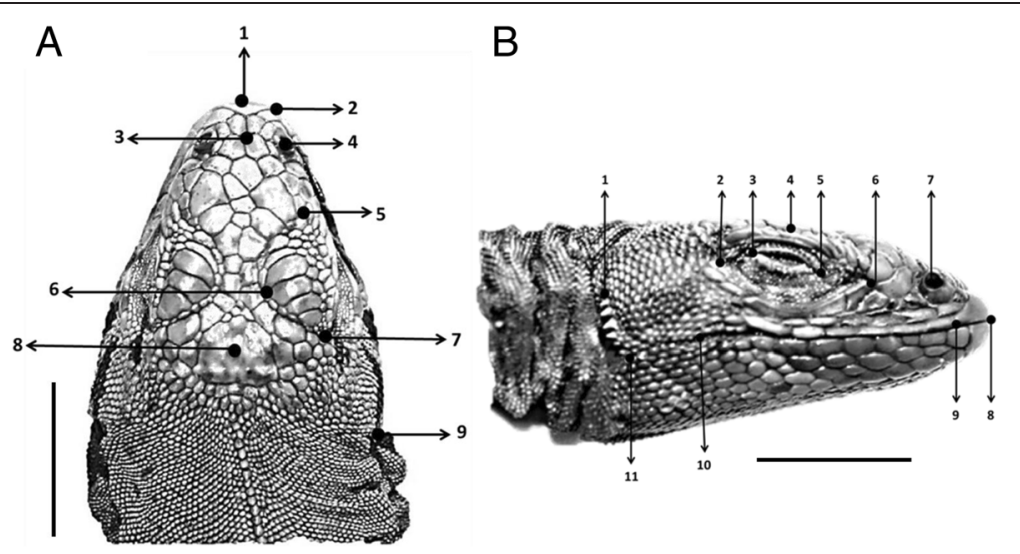

Figure 2 Landmarks selected for the dorsal (A) and lateral (B) views in Microlophus atacamensis. The lateral bar on each image represents $1 \mathrm{~cm}$ on the specimen.

superimposed using the minimum squares method based on the generalized Procrustes analysis (GPA), thus removing non-shape variation (Zelditch et al. 2004) in order to standardize the size and to translate and rotate the configurations of landmark coordinates using tpsRelw (Rohlf 2003b). We extracted relative warp scores, using the tpsRelw software according to Kaliontzopoulou et al. (2007). Using relative warps, we computed canonical scores for specimens of populations in order to visualize these variations. The deformation grids were produced by the regression of shape variables against canonical results (Rohlf 2003b). These variables are used in a multivariate analysis (Rohlf et al. 1996; Adams and Rohlf 2000). We used TpsRelw version 1.21 (Rohlf 2003b) to perform a principal component analysis.

To determine sexual dimorphism and variability among localities, we using an analysis of two-way MANOVA using sex and locality as factor on the matrix of relative warps. Centroid size was used as a size index, computed as the square root of the sum of the squared distances of a set of landmarks from their centroid (Marcus et al. 1996). The centroid size $(\log (\mathrm{CS}))$ of all individuals was compared with a two-way ANOVA using sex and locality as factor. The allometry calculations used in this work consisted of multivariate regression in which the explanatory variable is the CS, and the dependent variables are the variables of the shape (i.e., Procrustes residuals or PC scores, see Klingenberg 1996 and Depecker et al. 2006). According to Bookstein (1991), allometry is defined as changes in the shape related to the increase in size, where significant results in the multivariate regression of shape on CS indicate an allometric effect of size on shape (Zelditch et al. 2004).

\section{Results}

No significant differences were detected among localities, either in dorsal view (Wilk's lambda $=0.23 ; p=0.45$ ) or lateral view (Wilk's lambda $=1.77 ; p=0.24$ ), and no sexual dimorphism was found in dorsal (Wilk's lambda $=0.31$; $p=0.67$ ) and lateral (Wilk's lambda $=0.05 ; p=0.63$ ) views. The interaction between the two factors was not significant in both views, respectively (Wilk's lambda dorsal $=1.65 ; p=0.1 ;$ Wilk's lambda lateral $=1.06 ; p=$ 0.52). The first three principal components of shape explained the majority of the variance for the dorsal and lateral views $(96.9 \%$ and $86.6 \%$, respectively, Figures 3 and 4). In the dorsal view (Figure 3), PC1 expresses a change in the shape of the head laterally $(90.1 \%$ of the total Procrustes form variance), while in lateral view (Figure 4) it expresses the change in the posterior region (68.4\% of the total Procrustes form variance). In both cases, PC1 shows changes in allometry. PC2 in dorsal view (5.6\% of the total form variance) showing changes in the compression of the head on their sides; for the lateral view (12.6\% of the total form variance), it shows the changes with a dorsal-ventral compression. The PC3 accumulates low variance, which is displayed on the projected surface by the three components (Figures 3 and 4). In centroid size case, no significant differences were detected among localities, either in dorsal view $\left(F_{(1,4)}=6.57\right.$; $p=0.54)$ or lateral view $\left(F_{(1,4)}=0.21 ; p=0.93\right)$, and no sexual dimorphism was found in dorsal $\left(F_{(1,4)}=0.38 ; p=0.54\right.$ ) and lateral views $\left(F_{(1,4)}=0.06 ; p=0.81\right)$. The interaction between the two factors was not significant in both views, respectively $\left(F_{(1,4)}=1.19 ; p=0.15 ; F_{(1,4)}=0.24 ; p=0.91\right)$. Landmark 9 of the dorsal view and landmarks 1 and 11 of the lateral view were those which showed the greatest variation, corresponding to the tympanic area. Although no significant differences among localities were detected in both views, there is a tendency to differentiate the locations of Antofagasta from Caldera - Three Playitas in dorsal view, and Caldera from Tres Playitas - and Pan de Azúcar in lateral view. The spatial ordering of the principal components analysis (PCA) showed superimposition 

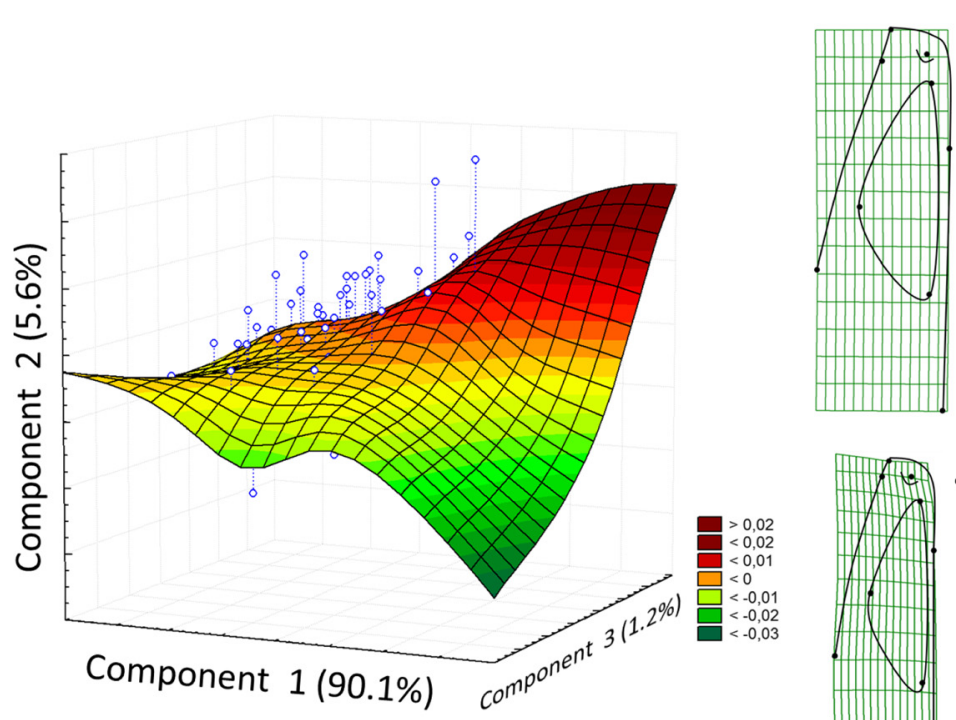

PC 1

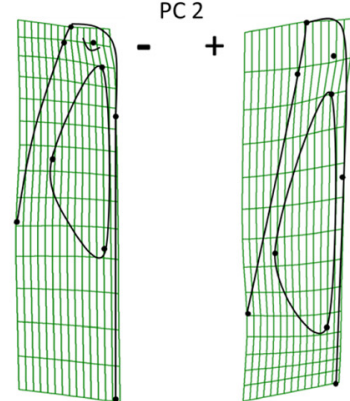

Figure 3 Form-space principal component analysis in Microlophus atacamensis in lateral view. The first three components account for 96.9\% of the total form-space variance. Surfaces correspond to the shapes represented by negative and positive extremes of PC1 and PC2.

of all localities in the dorsal and lateral views (Figure 5). No allometric effect was detected in either dorsal or lateral view for the shape variables between the centroid size and the principal components $(r=0.08, p=0.65$ in dorsal view; $r=0.02, p=0.83$ in lateral view).

\section{Discussion}

A number of studies have been performed on chromosomes, coloration, diet, thermoregulation, and geometric morphometrics which have provided evidence for clinal variation of lizards in Chile (Lamborot 1991; Lamborot et al. 2012; Vásquez et al. 2007; Vidal et al. 2007; Sepúlveda et al. 2008; Fariña et al. 2008; Vidal et al. 2008). In spite of these evidences, our results do not show clinal variation in head shape among the five studied localities of $M$. atacamensis. The PCA showed a superposition of all the localities both in dorsal and lateral view, indicating that the different morphs may be found in all the studied localities. However, this analysis showed some tendency to group the Pan de Azúcar and Tres Playitas localities in dorsal view, and Caldera and Tres Playitas in the lateral view (Figure 3). Although the results of the a posteriori analysis show a tendency of segregation in two relative warps in dorsal view and three in lateral view, the majority of the

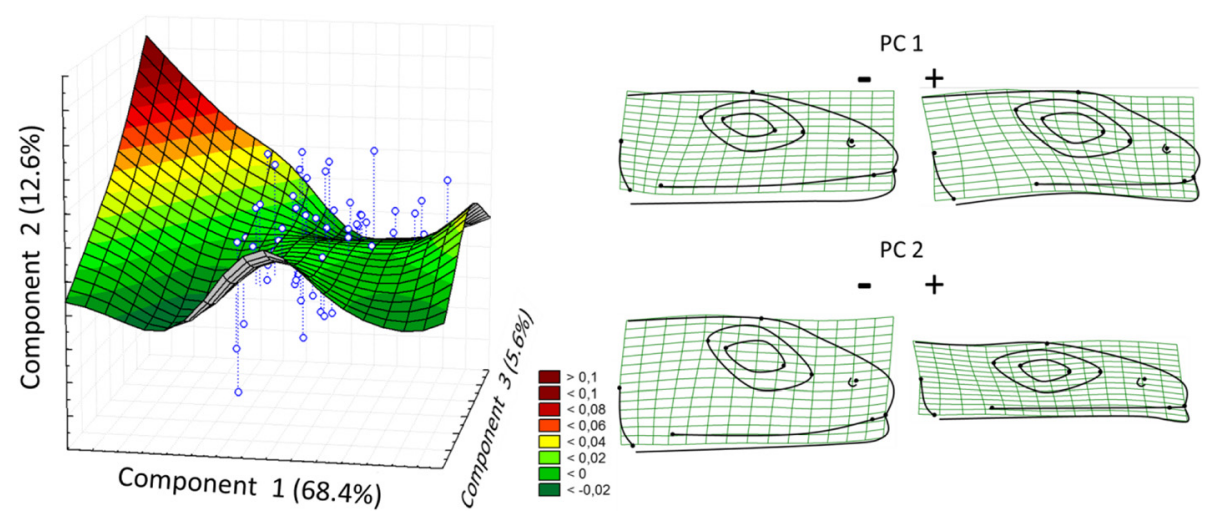

Figure 4 Form-space principal component analysis in Microlophus atacamensis in lateral view. The first three components account for $86.6 \%$ of the total form-space variance. Surfaces correspond to the shapes represented by negative and positive extremes of PC1 and PC2. 


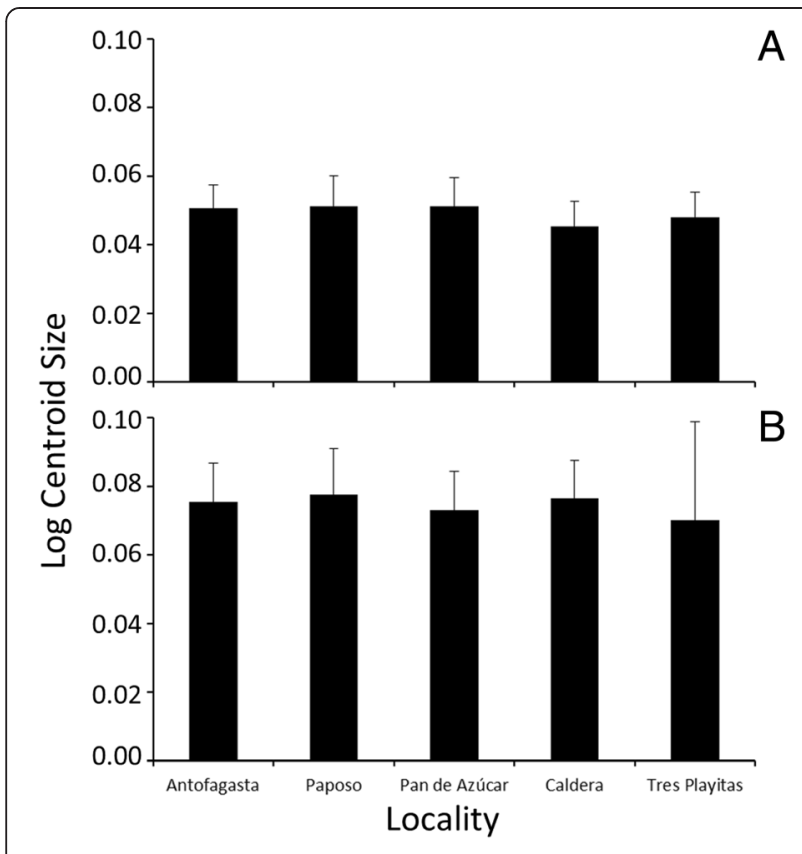

Figure 5 Centroid size (log) and standard deviation of the five localities in dorsal (A) and lateral (B) views.

results obtained did not show significant differences among localities. Although Fariña et al. (2008) showed a latitudinal gradient in the diet of $M$. atacamensis, we did not find a similar pattern in the shape of the head as shown in the study of Vidal et al. (2006) in L. pictus. Kaliontzopoulou et al. (2010) found significant different differences in the form of the head of Podarcis bocagei, related to the habitat utilized. In the present case, $M$. atacamensis uses the same habitat in its entire distribution range (Ortiz 1980b; Heisig 1993; Sepúlveda et al. 2006), which may explain in part the lack of clinal differences in head form. The same is true of L. petrophilus (Fontanella et al. 2012); although there are differences in the shape of the cranium from north to south, this is due to the fact that this species occupies different niches latitudinally. In Strengeriana maniformis, Pedraza and Campos (2007) did not find significant differences in the form of the gonopod among habits with and without mining contamination; they found, as in the present case, that the different morphs are distributed in both types of habitats, which may indicate that this species has some plasticity to mining contaminants. M. atacamensis may also have some plasticity in diet, depending upon the food available, explaining in part the lack of clinal variation in head form over a latitudinal range.

Also in this case, L. tenuis does not show a clinal variation pattern in its morphological characteristics (Vidal et al. 2005). By contrast, in M. atacamensis, Ortiz (1980a) showed that the number of mid-line scales and number of vertebral scales increased from Antofagasta to Huasco.
Also, Sepúlveda et al. (2008) hypothesized that in this species, size is related to the thermoregulatory gradient, since juvenile individuals (smaller) were the first to emerge in the morning and adults (larger) were the last to take refuge in the evening, suggesting that populations in the north should be smaller than those in the south. The lizard plays an important role in linking the intertidal and terrestrial environment within desert systems, since it feeds in the intertidal area (eating algae, isopods, and Diptera) and thermoregulates in the terrestrial area, defecating in the latter zone and thus contributing to its biomass and maintaining the trophic networks (Sepúlveda et al. 2006; Fariña et al. 2008). In this case, at larger sizes, there is increased bite force, improved prey handling efficiency, and a consequent shift to larger and harder foods (Verwaijen et al. 2002), therefore it was expected to yield a variation in the shape of the head of $M$. atacamensis. On the other hand, much importance has been given to the three-dimensional representation (3D) to estimate the variations due to the shape in an evolutionary context. According Polly and MacLeod (2008), the success of our 3D eigensurface method, while qualified, is encouraging. Eigensurface analysis of the 3D topography of calcanea sorted them into the same functional spectrum that qualitative functional analysis would have. While 3D surface scans of complicated morphological structures (e.g., bones, teeth, and shells) are increasingly easy to generate, this technique is not attainable for everyone, but we hope to conduct new studies to incorporate 3D images for population comparisons (Polly and MacLeod 2008).

On the other hand, according to Bruner et al. (2005), it is assumed that during development the scales either grow or do not grow but that no absolute reduction takes place. Concerning the length of the frontal scales, Bruner et al. (2005) suggest that males show an absolute enlargement but a relative reduction when compared to females (i.e., negative allometry) in sexual dimorphism case. In relation to clinal variation, there are no studies indicating that the scales tend to differ with latitude. However, using the scales as a reflection of the bones suggests that they are good indicators of change at this level (Costantini et al. 2007). In the case of M. atacamensis, there are no differences in head shape connecting to clinal variation, which involves conducting new studies to understand in an evolutionary context.

\section{Conclusions}

Our results show that there are no differences between the studied, among the explanations are that populations of this species are subjected to similar environments that promote convergence of the structures analyzed.

Competing interests

The authors declare that they have no competing interests. 


\section{Authors' contributions}

SI obtained photographs of museum specimens used in this study and contributed to the writing the manuscript. MV directed the photo shoots of the museum specimens used in this study. She directed the construction of the manuscript and the geometric and statistical analysis of the study. JCO provided the museum specimens that were photographed and provided input on improving the manuscript. FTP was involved in revising the manuscript and provided new ideas to improve the version sent. All authors read and approved the final manuscript.

\section{Acknowledgements}

We thank the Museo de Zoología of the Universidad de Concepción for supplying the samples used in this study. Finally, thanks to Lafayette Eaton, who made valuable suggestions which helped to improve this work. This study was financed by the Fondecyt project 1131009

\section{Author details}

'Departamento de Ciencias Básicas, Facultad de Ciencias, Universidad del Bío-Bío, Casilla 447, 4051381 Chillán, Chile. ²Departamento de Zoología, Facultad de Ciencias naturales y Oceanográficas, Universidad de Concepción, Casilla 160-C, Concepción, Chile. ${ }^{3}$ Instituto de Biología, P. Universidad Católica de Valparaíso, Av. Universidad 330, Campus Curauma, Valparaíso, Chile.

Received: 14 March 2014 Accepted: 25 December 2014

\section{Published online: 02 February 2015}

\section{References}

Adams D, Rohlf FJ (2000) Ecological character displacement in Pletodon: biomechanical differences found from a geometric morphometric study. Proc Natl Acad Sci U S A 97:4106-4111

Benavides E, Baum R, McClellan D, Sites JW (2007) Molecular phylogenetics of the lizard genus Microlophus (Squamata, Tropiduridae): aligning and retrieving indel signal from nuclear introns. Syst Biol 56:776-797

Bookstein FL (1991) Morphometrics tools for landmark data: geometry and biology. Cambridge University Press, New York

Bookstein F, Schafer K, Prossinger H, Seidler H, Fieder M, Striger C, Weber G, Arsuaga JL, Slice D, Rohlf FJ, Recheis W, Mariam A, Marcus L (1999) Comparing frontal cranial profiles in archaic and modern Homo by morphometric analysis. Anat Rec 257:217-224

Bruner E, Costantini D, Fanfani A, Dell'Omo G (2005) Morphological variation and sexual dimorphism of the cephalic scales in Lacerta bilineata. Acta Zool $86: 245-254$

Costantini D, Bruner E, Fanfani A, Dell'Omo G (2007) Male-biased predation of western green lizards by Eurasian kestrels. Naturwissenschaften 94:1015-1020

Depecker M, Berge C, Penin X, Renous S (2006) Geometric morphometrics of the shoulder girdle in extant turtles (Chelonii). J Anat 208:35-45

Dixon J, Wright J (1975) A review of the lizards of the Iguanid genus Tropidurus in Perú. Contr. Sci. Nat. Hist. Mus. Contr Sci Nat Hist Mus Los Angeles 271:1-39

Donoso-Barros R (1949) Alimentación de Tropidurus peruvianus (Lesson). Biol Mus Nac Hist Nat Chile 24:213-216

Donoso-Barros R (1960) Ecología de los reptiles Chilenos. Invest Zool Chil 6:65-72 Donoso-Barros R (1966) Reptiles De Chile. Universidad de Chile, Santiago, Chile, 458

Endler J (1977) Geographic variation, speciation, and clines. Princeton University Press, New Jersey

Etheridge R, de Queiroz K (1988) A phylogeny of Iguanidae. In: Estes RR, Pregill G (eds) Phylogenetic relationships of the lizard families: essays commemorating Charles L. Camp. Stanford.Univ. Press, Stanford CA, pp 283-367

Fariña JM, Sepúlveda M, Reyna MV, Wallem KP, Ossa-Zazzali PG (2008) Geographical variation in the use of intertidal rocky shores by the lizard Microlophus atacamensis on the Atacama Desert coast. J Anim Ecol 77:458-468

Fontanella FM, Feltrin N, Avila L, Sites JW, Morando M (2012) Early stages of divergence: phylogeography, climate modeling, and morphological differentiation in the South American lizard, Liolaemus petrophilus (Squamata: Liolaemidae). Ecol Evol 2:792-808

Frost DR (1992) Phylogenetic analysis and taxonomy of the Tropidurus group of lizards (Iguania: Tropiduridae). Am Mus Novit 3033:1-68

Frost DR, Etheridge R (1989) A phylogenetic analysis and taxonomy of iguanian lizards (Reptilia: Squamata). Mus Nat Hist Univ Kansas Misc Publ 81:1-65
Futuyma D (1998) Evolutionary biology, 3rd edn. Sinauer Associates, Inc., Sunderland, Massachusetts

Heisig M (1993) An etho-ecological study of an island population of Tropidurus atacamensis. Salamandra 29:65-81

Humphries JM, Bookstein FL, Chernoff B, Smith GR, Elder RL, Poss SG (1981) Multivariate discrimination by shape in relation to size. Syst Zool 30:291-308

Kaliontzopoulou A, Carretero MA, Llorente GA (2007) Multivariate and geometric morphometrics in the analysis of sexual dimorphism variation in Podarcis lizards. J Morphol 268:152-165

Kaliontzopoulou A, Carretero MA, Sillero N (2010) Geographic patterns of morphological variation in the lizard Podarcis carbonelli, a species with fragmented distribution. Herpetol J 20:41-50

Klingenberg CP (1996) Multivariate allometry. In: Marcus LF, Corti M, Loy A, Naylor GJP, Slice D (eds) Advances in morphometrics. Plenum Press, New York, pp 23-49

Lamborot M (1991) Karyotypic variation among populations of Liolaemus monticola (Tropiduridae), separated by riverine barriers at the Andean Range. Copeia 1991:1044-1059

Lamborot M, Ossa CM, Vásquez M (2012) Population cytogenetics of the "Northern Mod 1" chromosomal race of Liolaemus monticola Müller \& Helmich (Iguanidae) from Central Chile. Gayana 76:10-21

Marcus LF, Corti M, Loy A, Naylor GJP, Slice DE (1996) Advances in morphometrics. Plenum Press, New York

Martínez-Freiría F, Santos X, Pleguezuelos JM, Lizana M, Brito JC (2009) Geographical patterns of morphological variation and environmental correlates in contact zones: a multi-scale approach using two Mediterranean vipers. J Zool Syst Evol Res 47:357-367

Mitteroecker P, Gunz P (2009) Advances in geometric morphometrics. Evol Biol 36:235-247

Mousseau TA (1991) Landmarks in morphometrics, or the shape and size of morphometrics to come. Evolution 45:1991-1980

Ortiz JC (1980a) Estudios comparativos de algunas poblaciones de Tropidurus de la costa chilena. An Mus Hist Nat Valparaíso 13:267-280

Ortiz JC (1980b) Revisión taxonómica del género Tropidurus en Chile. Actas de la Primera Reunión Iberoamericana de Zoología de Vertebrados. Ediciones del Ministerio de Universidades e Investigación, La Rábida, España, pp 355-377

Ortiz JC, Serey I (1979) Análisis factorial de correspondencias de las especies del género Tropidurus en Chile. Rev Med Exp Chile 12:203-208

Pedraza M, Campos M (2007) Estudio de la variación morfológica del gonopodo de Strengeriana maniformis (Brachyura: Pseudothelphusidae) mediante aplicación de Morfometría Geométrica. Caldasia 29:143-152

Polly PD, MacLeod N (2008) Locomotion in fossil carnivora: an application of eigensurface analysis for morphometric comparison of 3D surfaces. Palaeontol Electron 11:1-13

Quatrini R, Albino A, Barg M (2001) Variación morfológica en dos poblaciones de Liolaemus elongatus Koslowsky 1896 (Iguania: Tropiduridae) del noroeste patagónico. Rev Chil Hist Nat 74:639-65

Rohlf FJ (1999) Shape statistics: Procrustes superimpositions and tangent space. J Classif 16:197-223

Rohlf FJ (2003a) TPSDIG. Version 1.22. Department of Ecology and Evolution, State University of New York, Stony Brook, NY, Website: http://life.bio.sunysb. edu/morph/

Rohlf FJ (2003b) TPSRELW. Version 1.21. Department of Ecology and Evolution, State University of New York, Stony Brook, NY, Website: http://life.bio.sunysb. edu/morph/

Rohlf FJ, Bookstein FL (1987) A comment on shearing as a method for size correction. Syst Zool 36:356-367

Rohlf FJ, Corti M (2000) Use of two-block partial least squares to study covariation in shape. Syst Zool 49:740-753

Rohlf JF, Marcus L (1993) A revolution in morphometrics. Trends Ecol Evol 8:129-132

Rohlf FJ, Slice D (1990) Extensions of the Procrustes method for the optimal superimposition of landmarks. Syst Zool 39:40-59

Rohlf FJ, Loy A, Corti M (1996) Morphometric analysis of old world Talpidae (Mammalia, Insectívora) using partial-warp scores. Syst Biol 45:344-362

Scolaro JA, Cei JM (1987) A multivariate analysis of morphometric and exosomatic characters of Iguanid lizards of the patagonian Liolaemus king complex. J Herpetol 21:343-348

Sepúlveda M, Vidal MA, Fariña JM (2006) Microlophus atacamensis (Atacama Desert Runner) predation. Herpetol Rev 37:224-225

Sepúlveda M, Vidal MA, Fariña JM (2008) Seasonal and geographic variation in thermal biology of the lizard Microlophus atacamensis (Squamata: Tropiduridae). J Thermal Biol 33:141-148 
Trussell GC (2000) Phenotypic clines, plasticity, and morphological trade-offs in an intertidal snail. Evolution 54:151-166

Vásquez M, Torres-Pérez F, Lamborot M (2007) Genetic variation within and between four chromosomal races of Liolaemus monticola in Chile. Herpetol J 17:149-160

Verwaijen D, Van Damme R, Herrel A (2002) Relationships between head size, bite force, prey handling efficiency and diet in two sympatric lacertid lizards. Funct Ecol 16:842-850

Victoriano P, Torres F, Ortiz JC, Parra L, Northland I, Capetillo J (2003) Variación aloenzimática y parentesco evolutivo en especies de Microlophus del grupo "peruvianus" (Squamata: Tropiduridae). Rev Chil Hist Nat 76:65-78

Vidal MA, Labra A (2008) Dieta de anfibios Y reptiles. In: Vidal MA, Labra A (eds) Herpetología de Chile. Science Verlag, Santiago, pp 453-482

Vidal M, Ortiz JC, Labra A (2002) Sexual and age differences in ecological variables of the lizard Microlophus atacamensis (Tropiduridae) from Northern Chile. Rev Chil Hist Nat 75:283-292

Vidal MA, Ortiz JC, Ramírez CC, Lamborot M (2005) Intraspecific variation in morphology and sexual dimorphism in Liolaemus tenuis (Tropiduridae). Amphibia-Reptilia 26:343-351

Vidal MA, Veloso A, Méndez MA (2006) Insular morphological divergence in the lizard Liolaemus pictus (Liolaemidae). Amphibia-Reptilia 27:103-111

Vidal MA, Ortiz JC, Labra A (2007) Sexual and geographic variation of color patterns in Liolaemus tenuis (Squamata, Liolaeminae). Gayana 71:27-33

Vidal MA, Ortiz JC, Labra A (2008) Intraspecific variation in a physiological thermoregulatory mechanism: the case of the lizard Liolaemus tenuis (Liolaeminae). Rev Chil Hist Nat 81:171-178

Warheit KI (1992) Proceedings of the Michigan morphometrics workshop. Syst Zool 41:392-395

Zelditch ML, Swiderski D, Sheets D, Fink WL (2004) Geometric morphometrics for biologists: a primer. Elsevier, London

\section{Submit your manuscript to a SpringerOpen ${ }^{\circ}$ journal and benefit from:}

- Convenient online submission

- Rigorous peer review

- Immediate publication on acceptance

- Open access: articles freely available online

- High visibility within the field

- Retaining the copyright to your article

Submit your next manuscript at $\gg$ springeropen.com 